\title{
Influence of a Strain Rate and Temperature on the Crack Tip Stress and Microstructure Evolution of Monocrystalline Nickel: a Molecular Dynamics Simulation
}

\author{
W. P. Wu $\mathbf{u}^{\mathrm{a}, 1}$ and Z. Z. Yao \\ ${ }^{a}$ Department of Engineering Mechanics, School of Civil Engineering, Wuhan University, Wuhan, \\ China \\ ${ }^{\mathrm{b}}$ Department of Mechanical Engineering, University of Wuppertal, Wuppertal, Germany \\ 1.wpwu@whu.edu.cn
}

УДК 539.4

\section{Влияние скорости деформации и температуры на напряжение у вершины трещины и развитие микроструктуры монокристаллического никеля: моделирование методом молекулярной динамики}

\author{
В. П. $\mathbf{B y}^{\mathrm{a}, 1}$, 3. Ж. Яо \\ а Факультет теоретической механики, кафедра гражданского строительства, Уханьский универ- \\ ситет, Ухань, Китай \\ ${ }^{\sigma}$ Факультет машиностроения, Университет Вупперталя, Вупперталь, Германия
}

Влияние скорости деформации и температуры на напряжение у вериины трещчины и развитие микроструктуры вблизи распространяющейся трещины в монокристаллическом никеле исследовали с помощью моделирования методом молекулярной динамики. Исследовали корреляцию между развитием микроструктуры и полем напряжений у вершины трещины. Результаты продемонстрировали, что характеристика распределения напряжений у вершины трещины и динамика распространения трещины тесно связаны с развитием микроструктуры, обусловленной изменением скорости деформации и температуры. При низких скорости деформации и температуре трещина распространяется по механизму хрупкого разрушения без воздействия на изменение расположения атомов у ее вериины. Концентрация напряжений возникает у вершины распространяющейся трещины. Распространение трещины характеризуется постепенным переходом от хрупкого разрушения к пластичному с увеличением температуры и скорости деформации. Максимальное напряжение сопровождается развитием микроструктуры у вериины трещиныь.

Ключевые слова: вершина трещины, атомное напряжение, развитие микроструктуры, монокристаллический никель, моделирование методом молекулярной динамики.

Introduction. The mechanical response of materials subject to applied stress is controlled by atomistic mechanisms in the vicinity of stress concentrations such as crack tips. Crack tips represent mathematical singularities for the stress distribution, providing local large interatomic forces that form the seeds for macroscopic failure [1,2]. Crack tip behavior in metals is among the most basic problems in mechanics of materials. A material exhibits intrinsically brittle behavior if an existing crack can propagate along certain crystallographic planes in a cleavage manner, whereas ductile fracture occurs when there is plastic deformation at the crack tip. The plastic processes at the crack tips, including dislocation emission, void nucleation, twinning, etc. have a pronounced effect on the crack 
propagation and stress distribution around the growing crack. When a pre-cracked crystal deforms plastically in the crack tip region within a certain range of temperature and strain rate, inhomogeneous dislocations are generated as a diverse form in the crystal [3]. At the macroscale, the strain rate and temperature effects have been studied for many ductile metals [4-7]. At the atomic scale, the response of fracture in the crystal metals to the strain rate and temperature is a complicated phenomenon, involving many micromechanisms, such as dislocation motions [8-10], twins [11-13], stacking faults [13], slip [14, 15], etc. This microstructural evolution of atoms around the crack tip may result in a change of the stress field around the crack tip and severely affect the fracture properties of material, such as the twins and dislocation slip, which may be considered as a contributing deformation mechanism and significantly affect the crack propagation [16]. At present, atomistic simulations have proved to be a useful tool for studying the crack tip plasticity and fracture properties of materials by investigating atomistic configuration and stress field around the crack tip from an atomistic standpoint [17-20]. Moreover, atomistic simulations of fracture events have produced observations that resemble characteristics at the macroscopic scales and yielded an important finding from atomistic simulation is that atomic stress plays a controlling role in nanoscale fracture [21-24]. Considering the strain rate and temperature have a significant effect on the crack tip plasticity and atomic stress field at the atomic scale, it is believed that the apparently large discrepancy among the crack tip plasticity and stress field exists at different temperatures and strain rates, which results in different crack tip microstructures and nanoscale fracture mechanisms. Therefore, it is necessary to investigate the effect of temperature and strain rate on the stress field and microstructure evolution near the crack tip, and it is also essential and important for understanding the nanoscale fracture properties at different strain rates and temperatures.

In this paper, we carry out molecular dynamics (MD) simulations to investigate the internal microstructure evolution and atomic stress distribution near the crack tip during crack propagation at different strain rates and temperatures. The objective of the present work is to characterize the influence of strain rate and temperature on the stress and microstructure evolution near the crack tip during crack propagation, as well as to determine the relationship between the change of the stress field near the crack tip and microstructure evolution at different strain rates and temperatures. Meanwhile, it also offers an explanation for the influence of the internal microstructure evolution on the crack opening displacement.

1. Atomistic Model and Simulation Process. In this work, we perform a MD simulation to investigate the effects of temperature and strain rate on crack tip stress and microstructure evolution of a growing crack in a pre-cracked single crystal nickel. The MD simulation describes motions of all atoms in a system by numerically solving Newton's equations and determines the material property by the inter-atomic potentials. For facecentered cubic (fcc) metallic materials the embedded-atom-method (EAM) is one of the most popular inter-atomic potentials $[25,26]$. The EAM potential proposed by Mishin et al. [27] is used here to simulate failure process of a pre-cracked single crystal nickel, considering that this potential is lucrative for description of the bonding in metallic systems and gives a reasonable simulation of fracture and damage. In this MD simulation, a constrained three-dimensional model is employed for the study of crack propagation and failure process in fcc single crystal nickel at various temperatures and strain rates. The geometry of the crack propagation system is shown in Fig. 1a.

The crystal has a cubic orientation (i.e., $X-[100], Y-[010]$, and $Z-[001]$ ). The crystal dimension in the $X$-axis is chosen to be sufficiently large so that steady-state crack propagation is obtained during MD simulations. The atoms in the top and bottom layers, which have a thickness of potential cut-off distance, are fixed. Periodic boundary conditions are formulated in the $X$ and $Z$ directions, and non-periodic boundary conditions are applied in the $Y$ direction. In the model (Fig. 1a), a single crack is inserted into the center of crystal 
by removing atoms, the size of the model is $150 a \times 100 a \times 6 a(528 \AA \times 352 \AA \times 21.12 \AA)$, while the initial crack length is equal to $10 a(35.2 \AA)$, and its width - to the lattice constant of nickel $a(a=3.52 \AA)$. The initial atomic configuration near the crack tip is shown in Fig. 1b. To study the effects of strain rate and temperature on the stress and microstructure evolution near the crack tip during crack propagation, we set up four different strain rates $1 \cdot 10^{8}, 2 \cdot 10^{8}, 5 \cdot 10^{8}$, and $1 \cdot 10^{9} \mathrm{~s}^{-1}$ and four different temperatures $5,100,300$, and $500 \mathrm{~K}$, respectively. At the start of simulation, this atomic system is relaxed using the conjugate gradient method to reach the minimum energy state. Then the relaxed system is stretched in the $Y$ direction by an incrementally displacement loading every 20 ps, by keeping the top and bottom boundaries parallel. The deformed configuration of the system is computed by the MD simulation, which is carried out by integrating Newton's equations of motion for all atoms using a time step of $1 \cdot 10^{-15} \mathrm{~s}$. The open source MD code LAMMPS [28] and the AtomEye visualization tools [29] are used in the atomistic simulations.
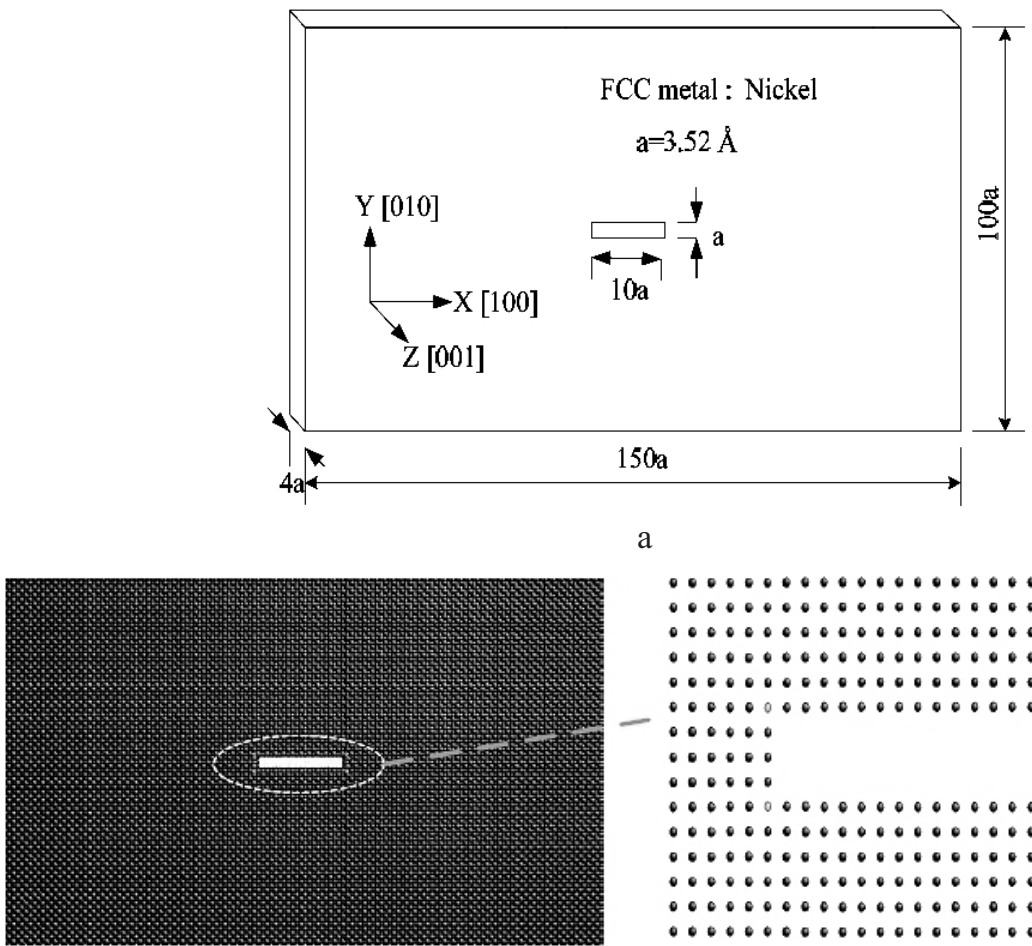

a

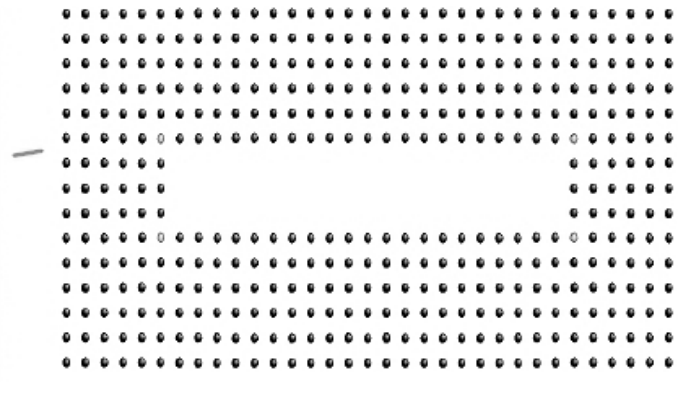

b

Fig. 1. Atomistic model: (a) sample geometry of a fcc single crystal nickel containing a single centered crack and (b) initial atomic configuration.

To study the nanoscale fracture behavior and analyze the atomic stress fields near the crack tip in the process of fracture, the atomistic stress definition is employed in this work. The atomic stress at an atom $i$ is a stress quantity at the atomic scale. This is the strength measurement of the interatomic interactions of the atom with its neighboring atoms. This atomic stress tensor is defined in the component form by the following equation [30]:

$$
\sigma_{\alpha \beta}(i)=-\frac{1}{2 \Omega_{i}} \sum_{j \neq(i)}^{N} f_{\alpha}(i, j) r_{\beta}(i, j),
$$


where $\Omega_{i}$ is the volume of atom $i\left(\Omega_{i}=\frac{4}{3} \pi R_{i}^{3}, R_{i}\right.$ is the radius of atom $\left.i\right), N$ is the number of atoms in a region around atom $i$ within the EAM potential cut-off distance (which is $4.80 \AA$ for $\mathrm{Ni}$ ), $f_{\alpha}(i, j)$ is the vector component form of the interaction force exerted by atom $j$ to atom $i$, whereas $r_{\beta}(i, j)$ is the vector component form of the relative position from atom $j$ to atom $i$.

Taking an average value over the volume around atom $i$ within the potential cut-off distance, the average atomic stress tensor $\bar{\sigma}_{\alpha \beta}$ for atom $i$ is given by [31]:

$$
\bar{\sigma}_{\alpha \beta}(i)=\frac{1}{N} \sum_{j=1}^{N} \sigma_{\alpha \beta}(j) .
$$

\section{Simulation Results.}

2.1. Effect of Strain Rate on the Crack Tip Stress and Microstructure Evolution. Figure 2 presents a detailed observation on the stress distributions and atomic configurations around the crack tip for four different strain rates at $5 \mathrm{~K}$. When the crystal is stretched to the same amount of strain $\varepsilon=0.07$ at four different strain rates, the crack tip atoms exhibit different configurations and stress levels. For a lower strain rate $\left(1 \cdot 10^{8} \mathrm{~s}^{-1}\right)$, the crack is extended at a considerable distance and approaches fracture. The stress is concentrated directly at the crack tip without inducing the change of atomic configuration as shown in Fig. 2a. At the strain rate of $2 \cdot 10^{8} \mathrm{~s}^{-1}$, the atomic configuration and stress distribution at the crack tip are similar to those at a lower strain rate of $1 \cdot 10^{8} \mathrm{~s}^{-1}$, but the crack length is smaller and the peak stress value at the crack tip is lower (Fig. 2b). With the increase in the strain rate, it is found that the crack propagation increment at a lower strain rate of $2 \cdot 10^{8} \mathrm{~s}^{-1}$ is larger than those at higher strain rates $\left(5 \cdot 10^{8}\right.$ and $\left.1 \cdot 10^{9} \mathrm{~s}^{-1}\right)$, while the peak stress at the crack tip is also higher, as shown in Fig. $2 \mathrm{~b}-\mathrm{d}$. Moreover, it is also observed that the change of atomic configuration at the crack tip at a higher strain rate when the strain reaches the same value $\varepsilon=0.07$, the crack tip blunting occurs ahead of a growing crack due to the dislocation emission at a higher strain rate of $1 \cdot 10^{9} \mathrm{~s}^{-1}$. This reveals that the crack tip microstructure evolution is easier to occur at a higher strain rate when the strain reaches the same value. As it was observed above, at lower strain rates the crack propagation occured by the brittle mechanism without inducing any microstructure evolution in the single crystal nickel at $5 \mathrm{~K}$. The stress is always concentrated at the crack tip of growing crack through the crack propagation process. With increase in the strain rate, the crack propagation behavior exhibits a gradually developing transition from brittle to ductile pattern, the dislocations are emitted at the crack tip and induce the crack tip blunting, while the peak stress occurs in the crack-blunting region surrounding the crack front.

\subsection{Effect of Temperature on the Crack Tip Stress and Microstructure Evolution.} For the loading time of $t=360 \mathrm{ps}$, Fig. 3 shows the crack propagation states, stress distributions and microstructure characteristics near the crack tip at the same strain rate of $2 \cdot 10^{8} \mathrm{~s}^{-1}$ and different temperatures. At the temperature of $T=5 \mathrm{~K}$, the stress concentration occurs at the crack tip without inducing any microstructure evolution, as is shown in Fig. 3a. When the temperature is increased, the ability of atomic motion is enhanced, and dislocations become more mobile due to the thermal activation, whereas the atomic configuration is also changed at elevated temperature. At $T=100 \mathrm{~K}$, the atomic configuration near the crack tip is changed, a void is formed where the atomic tensile stress has the highest value at a certain distance ahead of the crack tip, this peak stress being accompanied by the appearance of the void at the location of the stress concentration (Fig. $3 b$ ). At $T=300 \mathrm{~K}$, it is observed that numerous dislocations are emitted ahead of the 
Tensile stress distribution
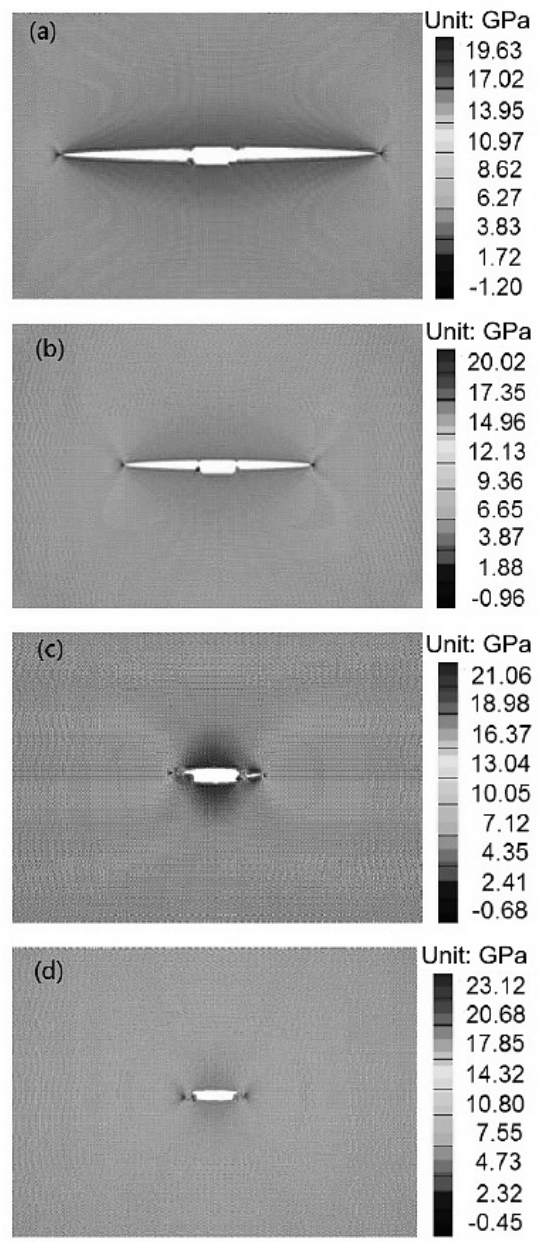

Microstructure near right hand crack tip
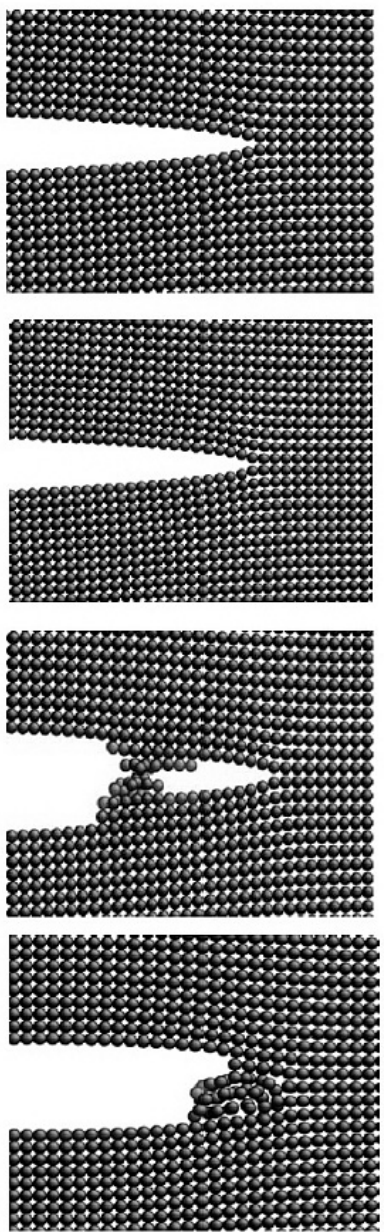

Fig. 2. Contour plots of the atomic tensile stress distributions and microstructures near right hand crack tip at strain $\varepsilon=0.07$ for different strain rates: (a) $1 \cdot 10^{8} \mathrm{~s}^{-1}$; (b) $2 \cdot 10^{8} \mathrm{~s}^{-1}$; (c) $5 \cdot 10^{8} \mathrm{~s}^{-1}$; (d) $1 \cdot 10^{9} \mathrm{~s}^{-1}$.

crack tip, which dislocations hinder the crack propagation along the original direction. It is recognized that atoms in the region of microstructure evolution have significantly higher stress and energy values than bulk atoms, whereas the crack is expected to propagate along the direction where the newly created surface energy is the lowest, so the crack propagation deviates from the original direction as shown in Fig. 3c. When temperature is further increased, the atoms near the crack tip emit a larger number of dislocations and induce the crack tip blunting at $T=500 \mathrm{~K}$. The crack propagation becomes slower at a higher temperature of $T=500 \mathrm{~K}$ due to the crack blunting surrounding the crack front. The concentration of the atomic tensile stress occurs in a blunting region ahead of the crack tip, and the peak stress is about $17 \mathrm{GPa}$ as shown in Fig. 3d. The analysis of the microstructure characteristics testifies that the temperature change induces the microstructure evolution (dislocation generation or void nucleation) at a certain distance ahead of the crack tip. Simultaneously, the microstructure evolution induces the variation of the stress field around the crack tip. Figure 3 shows a one-to-one relationship between the stress distributions and microstructure characteristics near the crack tip at different temperatures. These are plots of 


\section{Tensile stress distribution}
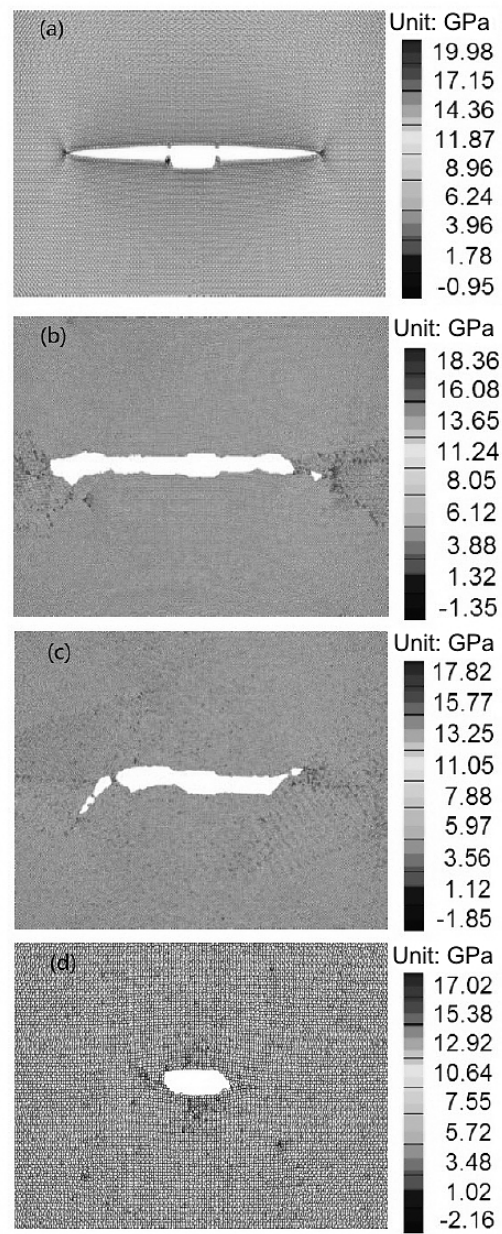

Microstructure near right hand crack tip
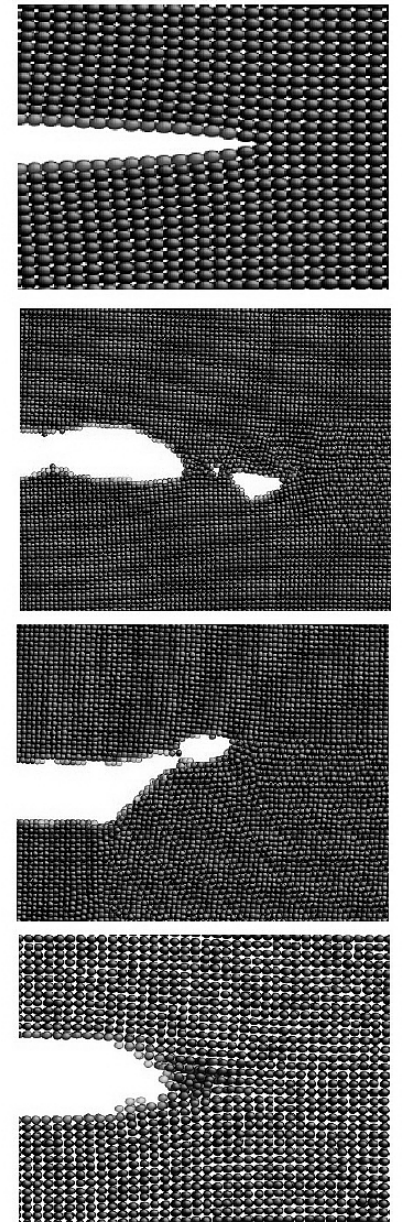

Fig. 3. Contour plots of the atomic tensile stress distributions and microstructures near right hand crack tip at loading time of $t=360 \mathrm{ps}$ and different temperatures: (a) $T=5 \mathrm{~K}$; (b) $T=100 \mathrm{~K}$; (c) $T=300 \mathrm{~K}$; (d) $T=500 \mathrm{~K}$.

the stress field and microstructure evolution at different temperatures illustrating different crack tip plasticity and crack propagation process. There is a gradual change of influence from dislocation non-generation at $5 \mathrm{~K}$ to the void formation and crack tip blunting surrounding the crack front with increasing temperature.

\subsection{Crack Opening Displacement at Different Strain Rates and Temperatures.} Crack opening displacement (COD) is an important aspect for understanding the crack growth and fracture behavior. In order to show quantitatively the strain rate and temperature effects on the crack resistance and crack propagation dynamics, COD is calculated at different strain rates and temperatures. The results for the COD as a function of atom position for different strain rates and temperatures are shown in Fig. 4. When the strain reaches the same value $\varepsilon=0.07$ at four different strain rates, it can be seen that the COD has the maximum value (approximately $9 \AA$ ) at the lower strain rate of $1 \cdot 10^{8} \mathrm{~s}^{-1}$, and the COD pattern along the crack path has a symmetry relative to the crack center. The COD value decreases with increase in the strain rate, and the COD along the crack path becomes more and more asymmetrical (Fig. 4a). The main reason for the COD variation is the 


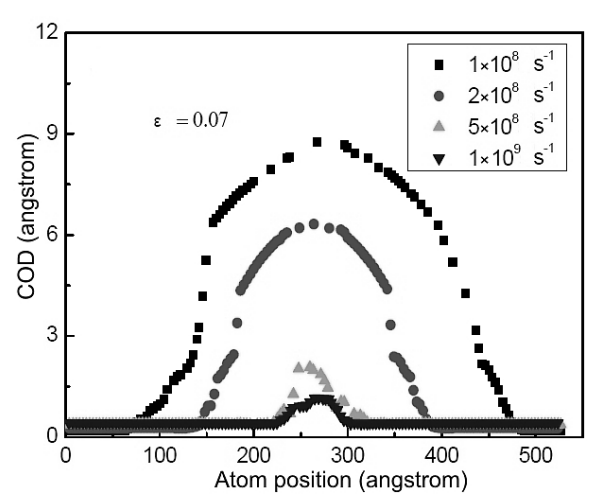

a

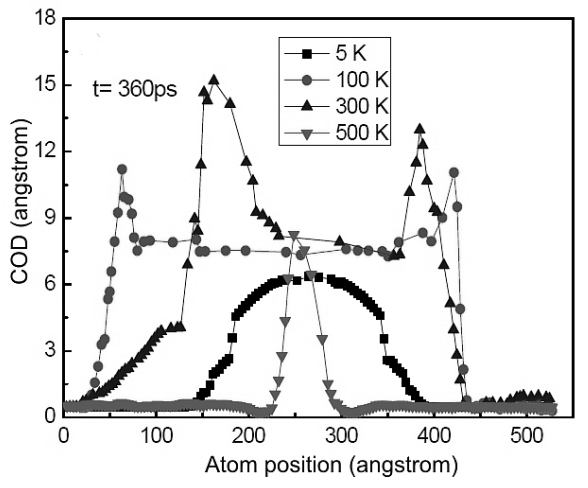

b

Fig. 4. Crack opening displacement (COD) as a function of atom position for a single crystal nickel: (a) at different strain rates; (b) at different temperatures.

microstructure evolution near the crack tip at the higher strain rate. Figure $4 \mathrm{~b}$ shows the $\mathrm{COD}$ as a function of atom position at the loading time of $t=360 \mathrm{ps}$ and different temperatures. At $T=5 \mathrm{~K}$, the COD is about $7 \AA$, and the COD along the crack path is symmetrical relative to the crack center. The COD increases with the temperature increase, and the largest COD value of $16 \AA$ is attained at $T=300 \mathrm{~K}$, while the COD along the crack tip becomes asymmetric due to the fact that temperature variation induces the microstructure evolution near the crack tip. When the temperature is raised to $500 \mathrm{~K}$, the COD is about $9 \AA$, the crack arrests and hardly propagates at the same loading time $(t=360 \mathrm{ps})$ because of a larger number of dislocation emissions at the crack front hindering the crack propagation. The above results indicate that the COD is closely related to the microstructure evolution near the crack tip for different strain rates and temperatures.

Conclusions. The MD simulations have been performed to study crack tip stress and microstructure evolution of a pre-cracked single crystal nickel at different strain rates and temperatures. The results indicate that the strain rate and temperature have a strong effect on the crack tip stress and microstructure evolution. When the same value of deformation is reached at different strain rates, in case of lower strain rates, the crack propagates rapidly without inducing any microstructure evolution at the crack tip, while the stress concentration occurs at the crack tip of a growing crack. At increased strain rates, the crack propagation becomes slower due to the change of atomic configuration at the crack tip. There is a gradually developing transition from brittle to ductile pattern, where the dislocations are emitted at the crack tip and induce the crack tip blunting, the peak stress occurring in the crack blunting region. For different temperatures, it is shown that crack propagates rapidly in a brittle manner at $5 \mathrm{~K}$, and the stress is directly concentrated at the crack tip without inducing the change of atomic configuration. Crack propagation becomes slower or deviates from the original crack path at elevated temperatures due to the microstructure evolution ahead of the crack tip. In this case, the peak stress occurs at the location of the microstructure evolution. With further increase in the temperature, the crack arrests and hardly propagates due to the fact that emitted dislocations induce crack tip blunting at the crack front. Furthermore, the crack opening displacement and the stress field variations at different strain rates and temperatures are shown to be closely related to the microstructure evolution near the crack tip caused by the strain rate and temperature variations.

The presented results have been obtained for a special atomistic configuration and a certain range of strain rates and temperatures. The crystal orientation, the atomic potential and constrain conditions, etc. also influence the crack tip stress and microstructure evolution. A more detailed and extensive MD model is necessary to provide more general 
insight into the crack tip stress and microstructure evolution characteristics at the atomic level.

Acknowledgements. The work was supported by National Natural Science Foundation of China (Grant No. 11102139), and China Postdoctoral Science Foundation (Grant Nos. 20110491205 and 2012T50665).

\section{Резюме}

Вплив швидкості деформації і температури на напруження у вістрі тріщини і розвиток мікроструктури поблизу тріщини, що розповсюджується, в монокристалічному нікелі досліджували за допомогою моделювання методом молекулярної динаміки. Досліджували кореляцію між розвитком мікроструктури і полем напружень у вістрі тріщини. Результати показали, що характеристика розподілу напружень у вістрі тріщини і динаміка поширення тріщини тісно пов'язані з розвитком мікроструктури, зумовленої зміною швидкості деформації і температури. За низьких швидкості деформації і температури тріщина поширюється по механізму крихкого руйнування без впливу на зміну розташування атомів у її вістрі. Концентрація напружень виникає у вістрі тріщини, що поширюється. Поширення тріщини характеризується поступовим переходом від крихкого руйнування до пластичного 3 підвищенням температури i швидкості деформації. Максимальне напруження супроводжується розвитком мікроструктури у вістрі тріщини.

1. J. R. Rice and R. Thomson, "Ductile versus brittle behavior of crystals," Phil. Mag., 29, Issue 1, 73-97 (1974).

2. M. J. Buehler and H. Gao, "Dynamical fracture instabilities due to local hyperelasticity at crack tips," Nature, 439, 307-310 (2006).

3. S. M. Byon, H. S. Kim, and Y. Lee, "Investigation of the size effect on the crack propagation using finite element method and strain gradient plasticity," J. Mater. Process. Technol., 191, No. 1-3, 193-197 (2007).

4. D. H. Sastry, Y. V. R. K. Prasad, and S. C. Deevi, "Influence of temperature and strain rate on the flow stress of an FeAl alloy," Mater. Sci. Eng. A, 299, No. 1-2, 157-163 (2001).

5. M. Shazly, V. Prakash, and S. Draper, "Mechanical behavior of Gramma-Met PX under uniaxial loading at elevated temperatures and high strain rates," Int. J. Solids Struct., 41, No. 22-23, 6485-6503 (2004).

6. I. M. Low and Y. W. Mai, "Rate and temperature effects on crack blunting mechanisms in pure and modified epoxies," J. Mater. Sci., 24, No. 5, 1634-1644 (1989).

7. F. Massa, R. Piques, and A. Laurent, "Rapid crack propagation in polyethylene pipe: combined effect of strain rate and temperature on fracture toughness," J. Mater. Sci., 32, No. 24, 6583-6587 (1997).

8. J. R. Rice, "Dislocation nucleation from a crack tip: An analysis based on the peierls concept," J. Mech. Phys. Solids, 40, No. 12, 239-271 (1992).

9. W. P. Wu, Y. F. Guo, and Y. S. Wang, "Evolution of misfit dislocation network and tensile properties in Ni-based superalloys: a molecular dynamics simulation," Sci. China-Phys. Mech. Astron., 55, No. 3, 419-427 (2012).

10. V. Yamakov, D. Wolf, M. Salazar, et al., "Length-scale effects in the nucleation of extended dislocations in nanocrystalline Al by molecular dynamics simulation," Acta Mater., 49, No. 14, 2713-2722 (2001). 
11. R. P. Reed, "Deformation twinning in Ni and F.C.C. Fe-Ni alloys," Phil. Mag., 15, No. 137, 1051-1055 (1967).

12. P. Haasen, "Plastic deformation of nickel single crystals at low temperatures," Phil. Mag., 3, No. 28, 384-418 (1958).

13. Y. F. Guo, C. Y. Wang, and Y. S. Wang, "The effect of stacking fault or twin formation on bcc-iron crack propagation," Phil. Mag. Lett., 84, No. 12, 763-770 (2004).

14. H. Traub, H. Neuhauser, and C. H. Schwink, "Investigations of the yield region of concentrated $\mathrm{Cu}-\mathrm{Ge}$ and $\mathrm{Cu}-\mathrm{Zn}$ single crystals - I. Critical resolved shear stress, slip line formation and the true strain rate," Acta Metall., 25, No. 4, 437-446 (1977).

15. C. Atkinson and C. Bastero, "Plastic relaxation at a crack tip by asymmetric slip," Proc. Roy. Soc. London A, 418, 261-280 (1854).

16. D. H. Warner, W. A. Curtin, and S. Qu, "Rate dependence of crack tip processes predicts twinning trends in f.c.c. metals," Nature Mater., 6, No. 11, 876-881 (2007).

17. K. S. Cheung and S. Yip, "A molecular-dynamics simulation of crack tip extension: the brittle-to ductile transition," Model. Simul. Mater. Sci. Eng., 2, No. 4, 865-892 (1994).

18. T. Kitamura, K. Yashiro, and R. Ohtani, "Atomic simulation on deformation and fracture of nano-single crystal of nickel in tension," JSME Int. J., Ser. A., 40, No. 4, 430-435 (1997).

19. C. W. Pao, S. M. Foiles, E. B. Webb III, et al., "Atomistic simulations of stress and microstructure evolution during polycrystalline Ni film growth," Phys. Rev. B, 79, No. 2, 224113 (2009).

20. R. Matsumoto, M. Nakagaki, A. Nakatani, and H. Kitagawa, "Molecular-dynamics study on crack growth behavior relevant to crystal nucleation in amorphous metal," CMES: Computer Modeling in Engineering \& Sciences, 9, No. 1, 75-84 (2005).

21. M. J. Buehler, H. Gao, and Y. Huang, "Atomistic and continuum studies of stress and strain fields near a rapidly propagating crack in a harmonic lattice," Theor. Appl. Fract. Mech., 41, No. 1-3, 21-42 (2004).

22. H. Krull and H. Yuan, "Suggestions to the cohesive traction-separation law from atomistic simulations," Eng. Fract. Mech., 78, No. 3, 525-533 (2011).

23. S. $\mathrm{Xu}$ and $\mathrm{X}$. Deng, "Nanoscale void nucleation and growth and crack tip stress evolution ahead of a growthing crack in a single crystal," Nanotechnology, 19, No. 11, 115705, DOI: 10.1088/0957-4484/19/11/115705 (2008).

24. W. P. Wu and Z. Z. Yao, "Molecular dynamics simulation of crack tip stress and microstructure evolution of a growing crack in single crystal nickel," Theor. Appl. Fract. Mech., 62, No. 12, 67-75 (2012).

25. M. S. Daw, S. M. Foiles, and M. I. Baskes, "The embedded-atom method: a review of theory and applications," Mater. Sci. Rep., 9, No. 7-8, 251-310 (1993).

26. M. F. Horstemeyer, M. I. Baskes, and S. J. Plimpton, "Computational nanoscale plasticity simulations using embedded atom potentials," Theor. Appl. Fract. Mech., 37, No. 1, 49-98 (2001).

27. Y. Mishin, D. Farkas, M. J. Mehl, and D. A. Papaconstantopoulos, "Interatomic potentials for monatomic metals from experimental data and ab initio calculations," Phys. Rev. B, 59, No. 5, 3393-3407 (1999).

28. S. J. Plimpton, "Fast parallel algorithms for short-range molecular dynamics," $J$. Comput. Phys., 117, 1-19 (1995). 
29. J. Li, "AtomEye: an efficient atomistic configuration viewer," Model. Simul. Mater. Sci. Eng., 11, 173-177 (2003).

30. M. Born and K. Huang, Dynamical Theory of Crystal Lattices, Clarendon, Oxford (1954).

31. M. F. Horstemeyer and M. I. Baskes, "Atomistic finite deformation simulations: a discussion on length scale effects in relation to mechanical stresses," J. Eng. Mater. Technol., 121, No. 2, 114-119 (1999).

Received 22. 11. 2013 